\title{
Scorpiops songi sp.n. and key to species of Scorpiops from China (Scorpiones: Scorpiopidae)
}

\author{
Scorpiops songi sp.n. и ключ для определения Scorpiops Китая \\ (Scorpiones: Scorpiopidae)
}

\author{
Zhiyong $\mathrm{Di}^{*}$, Sha Qiao \\ Жийонг Аи, Ша Киао
}

College of Life Science, Institute of Life Science and Green Development, Hebei University, Baoding 071002, Hebei, P.R. China

* Corresponding author: Zhiyong Di (zydi@ustc.edu.cn)

KEY WORDS: China, key, scorpion, Scorpiops, Xizang.

КЛЮЧЕВЫЕ СЛОВА: Китай, ключ для определения, скорпион, Scorpiops, Тибетский автономный округ.

ABSTRACT: A new species, Scorpiops songi sp.n., from Xizang (China), is described and illustrated. It is characterized by light yellow-brown color in living individuals, large size (length of adult male about 72.0 $\mathrm{mm}$ ), small and dense granules on integument, a pair of small median eyes (diameter $<0.5 \mathrm{~mm}$ ), 17 trichobothria ( $5 \mathrm{eb}, 2 \mathrm{esb}, 2 \mathrm{em}, 4 \mathrm{est}, 4 \mathrm{et}$ ) on the external surface of pedipalp patella and 7 or 8 trichobothria on the ventral surface of pedipalp patella, chela with a length/ width ratio about 2.4 in one adult male and average of 2.8 in two immature females, pedipalp chela fingers on adult females and males scalloped, pectinal teeth count 7 in five males and 6 in three females, pectinal fulcra vestigial. The number of known species of Scorpiops from China is raised to 16 , is more than half of the known species (29) in the world.

How to cite this article: Di Zhiyong, Qiao Sha. 2020. Scorpiops songi sp.n. and key to species of Scorpiops from China (Scorpiones: Scorpiopidae) // Arthropoda Selecta. Vol.29. No.3. P.316-324. doi: 10.15298/arthsel. 29.3.03

РЕЗЮМЕ: Дано иллюстрированное описание нового вида скорпионов Scorpiops songi sp.n. из Тибетского автономного округа, Китай. Новый вид характеризуется светлой желто-коричневой прижизненной окраской, большими размерами тела (длина взрослого самца около 72,0 мм), мелкой и густой зернистостью кутикулы, парой мелких срединных глаз (диаметр менее 0,5 мм), 17 трихоботриями (5 eb, $2 e s b, 2 e m, 4$ est, 4 et) на наружной поверхности пателлы педипальпы и 7 или 8 трихоботриями на ее вентральной поверхности, клешней педипальпы с соотношением длины/ширины около 2,4 у половозрелого самца и в среднем 2,8 у двух неполовозрелых самок, волнистым лезвием пальцев клешни педипальпы у половозрелых самок и самцов, 7 зубцами гребневидного органа у пяти самцов и 6 - у трех самок, фулькры слаборазвиты.
Число известных видов рода в Китае возросло до 16 , т.е. более половины видов мировой фауны, составляющей 29 видов.

\section{Introduction}

Scorpiops Peters, 1861 is the second large genus of the family Scorpiopidae Laurie, 1896, distributed mainly in South and Southeast Asia [Kovařík, 2000]. Near half of the known species of this genus found in China, mainly in Xizang.

Di et al. [2013-2015] recorded 11 Scorpiops species from China followed the literature [Bastawade, 2006; Di et al., 2011a, b; Qi et al., 2005; Zhu et al., 2004]: S. atomatus (Xizang), S. hardwickii (Xizang), S. jendeki (Yunnan), S. langxian (Xizang), S. leptochirus (Xizang), S. lhasa (Xizang), S. luridus (Xizang), $S$. margerisonae (Xizang), S. petersii (Xizang), S. pococ$k i$ (Xizang), and S. tibetanus (Xizang). Yin et al. [2015] described a new species: S. ingens (Xizang), and provided a key for these species. Li et al. [2016] erected another new species: S. jingshanensis from Jingshan County (Hubei Province) followed the description by Di et al. [2011a]. Lourenço [2018] described S. taxkorgan, based on the specimens collected at altitudes of 4500-4600 m, from the Taxkorgan Natural Reserve, Xinjiang (China). Kovařík [2020] described a new species, Scorpiops wrzecionkoi (Xizang). S. jingshanensis is the first record of the family Euscorpiidae from the central China. S. taxkorgan is the first record of this family from Xinjiang, also the highest and northernmost distribution record of this family. Here, we describe a new species from southern Xizang, as the genus Scorpiops becomes the largest genus of Chinese scorpion fauna. In China, including this new species, its 13 members were found in Xizang, other one from Hubei, one from Xinjiang and one from Yunnan (Maps 1, 2). 


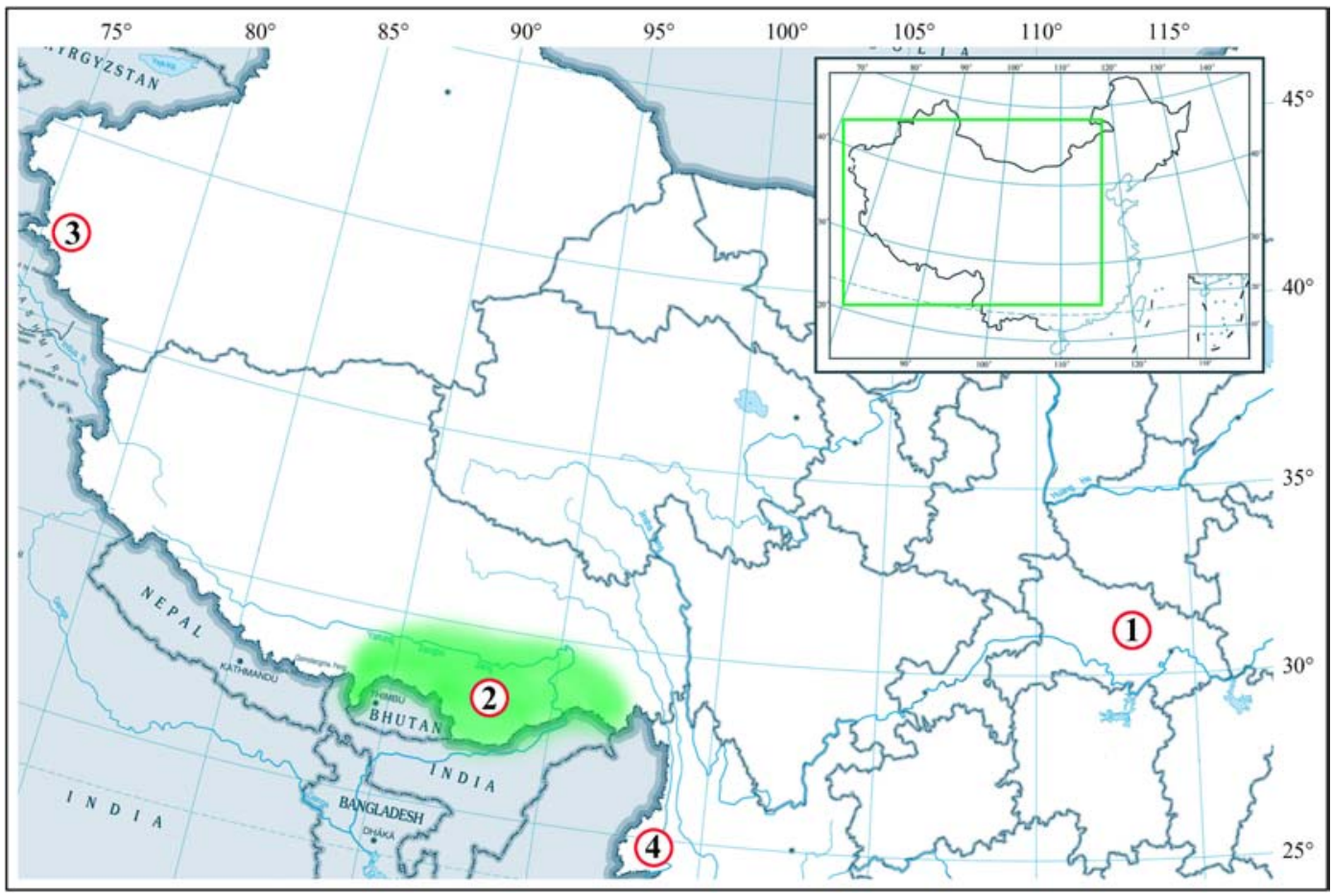

Map 1. Map of Central and Western China, showing the localities of Scorpiops species. 1 - S. jingshanensis from Hubei (Huzhao Mountains); 2 - the green part, presumed distribution area of Scorpiops species in Xizang; 3 - S. taxkorgan from Xinjiang (Taxkorgan Natural Reserve); $4-S$. jendeki from Yunnan (Gaoligong Mountains).

Карта 1. Местонахождения видов Scorpiops в Центральном и Западном Китае. 1 - S. jingshanensis (Xубей, горы Нuzhao); 2 закрашена область распространения Scorpiops в Тибетском автономном округе; 3 - S. taxkorgan (Синьцзян, Ташкурганский заповедник); 4 - S. jendeki (Юннань, горы Гаолигун).

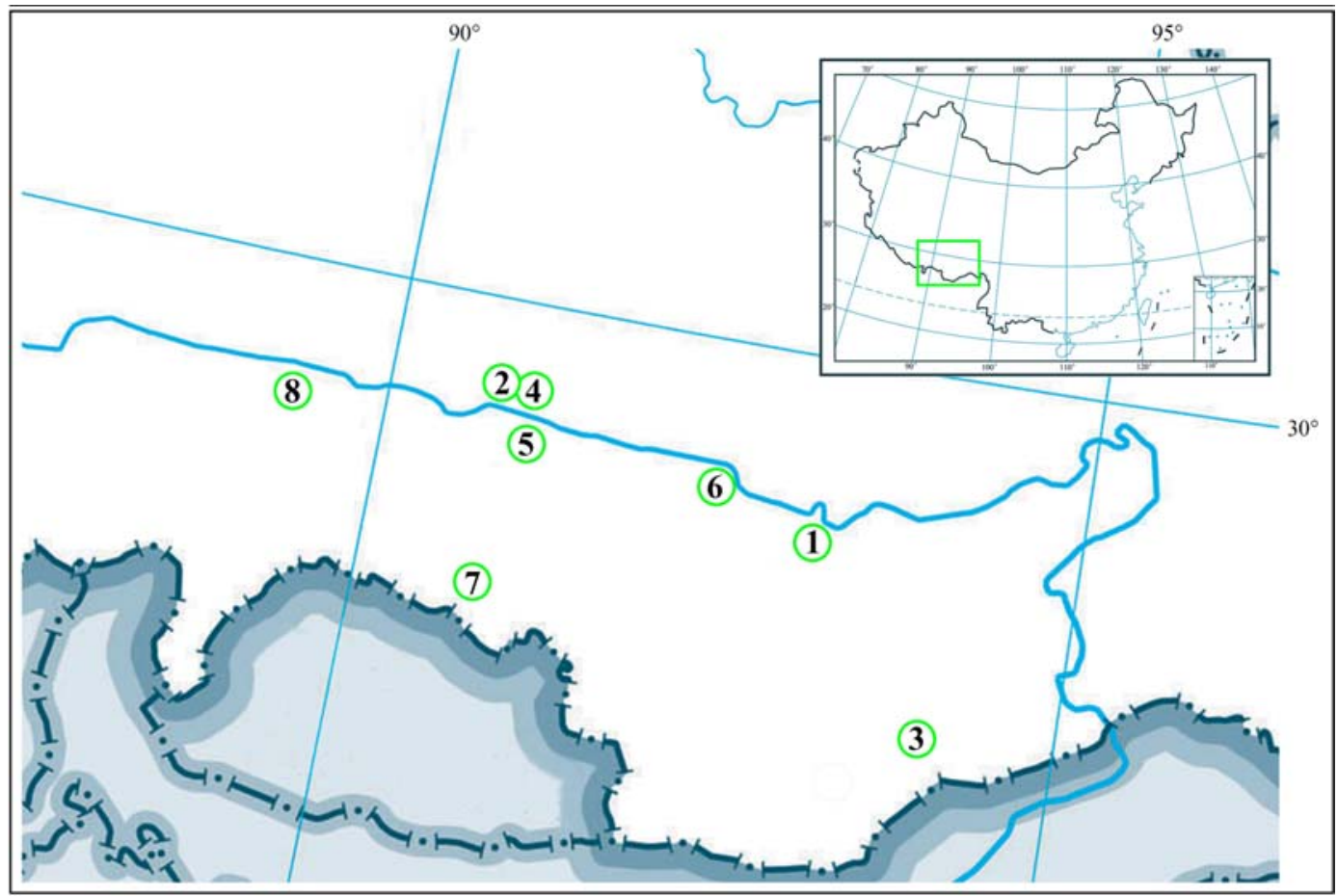

Map 2. Map of Xizang (China), showing the localities of Scorpiops species. 1 - type locality of $S$. atomatus, S. langxian and S. luroris; 2 - type locality of $S$. ingens; 3 - S. leptochirus; 4 - type locality of $S$. lhasa; 5 - S. margerisonae, and type locality of $S$. wrzecionkoi; 6 - type locality of Scorpiops pococki; 7 - type locality of S. songi sp.n.; 8 - S. tibetanus.

Карта 2. Местонахождения видов Scorpiops в Тибетском автономном округе. 1 - типовые местонахождения $S$. atomatus, $S$. langxian и $S$. luroris; 2 - типовое местонахождение $S$. ingens; 3 - S. leptochirus; 4 - типовое местонахождение $S$. lhasa; 5 - S. margerisonae, и типовое местонахождение $S$. wrzecionkoi; 6 — типовое местонахождение Scorpiops pococki; 7 — типовое местонахождение $S$. songi sp.n.; $8-S$. tibetanus. 


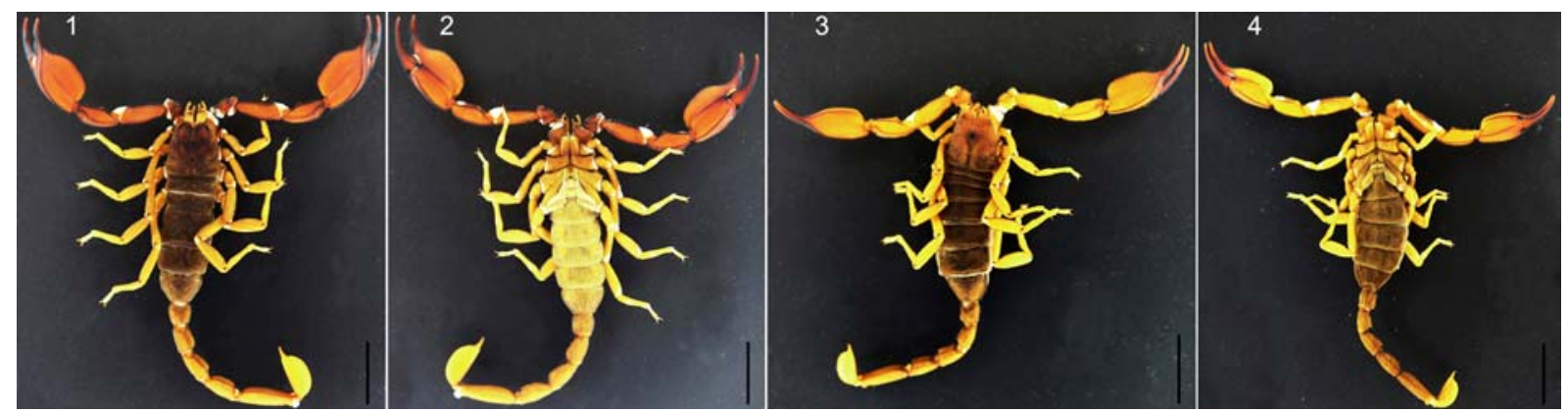

Figs 1-4. Habitus of Scorpiops songi sp.n. Dorsal and ventral habitus: 1, 2 - male holotype (Ar.-MHBU-XZLZ1501); 3, 4 - female paratype (Ar.-MHBU-XZLZ1502). Scale bar = $10.0 \mathrm{~mm}$.

Рис. 1-4. Внешний вид Scorpiops songi sp.n., дорсально и вентрально: 1, 2 - голотип самец (Ar.-MHBU-XZLZ1501); 3 , 4 паратип самка (Ar.-MHBU-XZLZ1502). Масштаб 10,0 мм.

\section{Material and methods}

Identification and measurements were made using a Motic K700 stereomicroscope with an ocular micrometer. The photos were taken with a Canon 650D camera and a Leica M205FA stereomicroscope (with a digital color microscope camera Leica DFC495). Measurements followed Sissom [1990)] and are given in mm. Trichobothrial notations followed Vachon [1974], and the morphological terminology mostly followed Hjelle [1990]. The terminology of metasomal carination followed Vachon [1952], and the terminology of pedipalp chelal carinae followed Soleglad \& Sissom [2001]. Type series of the new species are deposited in the Museum of Hebei University, Baoding, China (MHBU).

\section{Taxonomy}

Family Scorpiopidae Kraepelin, 1905 Genus Scorpiops Peters, 1861

\section{Scorpiops songi sp.n. Figs 1-33, Table 1.}

TYPE MATERIAL: Holotype male (MHBU), China: Xizang, Lhozhag County (Luozha County), 6/VIII/2015, Zhiyong Di leg. (Ar.-MHBU-XZLZ1501); paratypes: 1 immature and 3 juvenile males, 3 immature females, same location data as holotype (Ar.MHBU-XZLZ1502-08).

DIAGNOSIS. In accordance with the grouping of species proposed for the genus Scorpiops [Kovarrík, 2000; Kovařík, Ahmed, 2009; Kovařík, 2020], the new species differs from other members of the group in having light yellow-brown color, large size (length of adult male about $72.0 \mathrm{~mm}$ ), small and dense granules on the integument, 17 trichobothria (5 eb, $2 \mathrm{esb}, 2 \mathrm{em}, 4 \mathrm{est}, 4 \mathrm{et}$ ) on the external surface of pedipalp patella and 7 or 8 trichobothria on the ventral surface of pedipalp patella, chelae with a length/ width ratio about 2.4 in one adult male and an average of 2.8 in two immature females, pedipalp chela fingers on adult females and males scalloped, pectinal teeth count 7 in males and 6 in females, pectinal fulcra vestigial.

ETYMOLOGY. Patronym in honor of Prof. Daxiang Song (Hebei University), who greatly contributed to arachnid science in China.
DESCRIPTION. Based on male holotype.

Coloration. Mostly light yellow-brown after soaked in $75 \%$ alcohol more than one year (Figs 1-2). Carapace light yellow-brown with unconspicuous dark stripe (Figs 5, 6), median and lateral ocular tubercles black. Tergites and metasoma segments light yellow-brown (Figs 1-2, 11). Vesicle light yellow with a yellow-brown aculeus (Fig. 15). Chelicerae yellow, with fingers black-brown and gradually lighter toward the tip. Pedipalp light yellow-brown, with the carinae black-brown (Figs 1-2). Legs light yellow-brown. Claws yellow with yellow-brown tips. Sternum and sternites light yellow-brown (Figs 4, 13). Genital operculum, basil piece and pectines light yellow-brown (Fig. 13).

Morphology. Prosoma: Carapace coarse, with dense and minute granules, with sparse and large granules in the area of the front of the eye and nearby area; lateral furrow broad and flat; anterior median furrow broad and shallow; posterior median furrow deep; anterior margin nearly smooth; posterior and lateral margins and other parts with dense, minute granules (Figs 5,6). Median eyes small and same as the first lateral eyes, situated anterior to the center of the carapace; three pairs of lateral eyes, the third smallest (Figs 5, 6). Median ocular tubercle high and smooth, with a shallow median furrow. Lateral ocular tubercle with some bigger smooth granules.

Mesosoma: Tergites completely densely covered with equal minute granules in male holotype, but posterior part with some bigger granules in immature female and immature male paratypes; from tergite II to VI the trace of a median carina first appears and gradually becomes distinct; on tergite VII with a distinct apophysis and two pairs of lateral carinae. Sternum pentagonal with few setae (Fig. 13). Pectinal teeth count 7 in males, fulcra vestigial (Fig. 13). Genital opercula subtriangular with few setae (Fig. 13). Sternites III-VI smooth and shiny with few setae (Fig. 2); segment VII ventrally with four weak carinae and few setae.

Metasoma: Tegument coarse with few setae. Segments I to $\mathrm{V}$ are longer than wide; segments I to $\mathrm{V}$ have $10-8-8-8-7$ carinae, segments II-IV with a pair of vestigial lateral carinae; all carinae granular; on segment $\mathrm{V}$, ventral carinae with larger serration. Vesicle with dense granules and few setae (Fig. 15).

Chelicerae: Tibiae smooth with many long hairs on ventral aspect. Movable finger with 4 denticles on dorsal edge and 6 denticles on ventral edge. Fixed finger with 3 denticles on dorsal edge.

Pedipalps: Tegument smooth with smooth granules and few setae. Femur with dorsointernal, dorsoexternal, exter- 

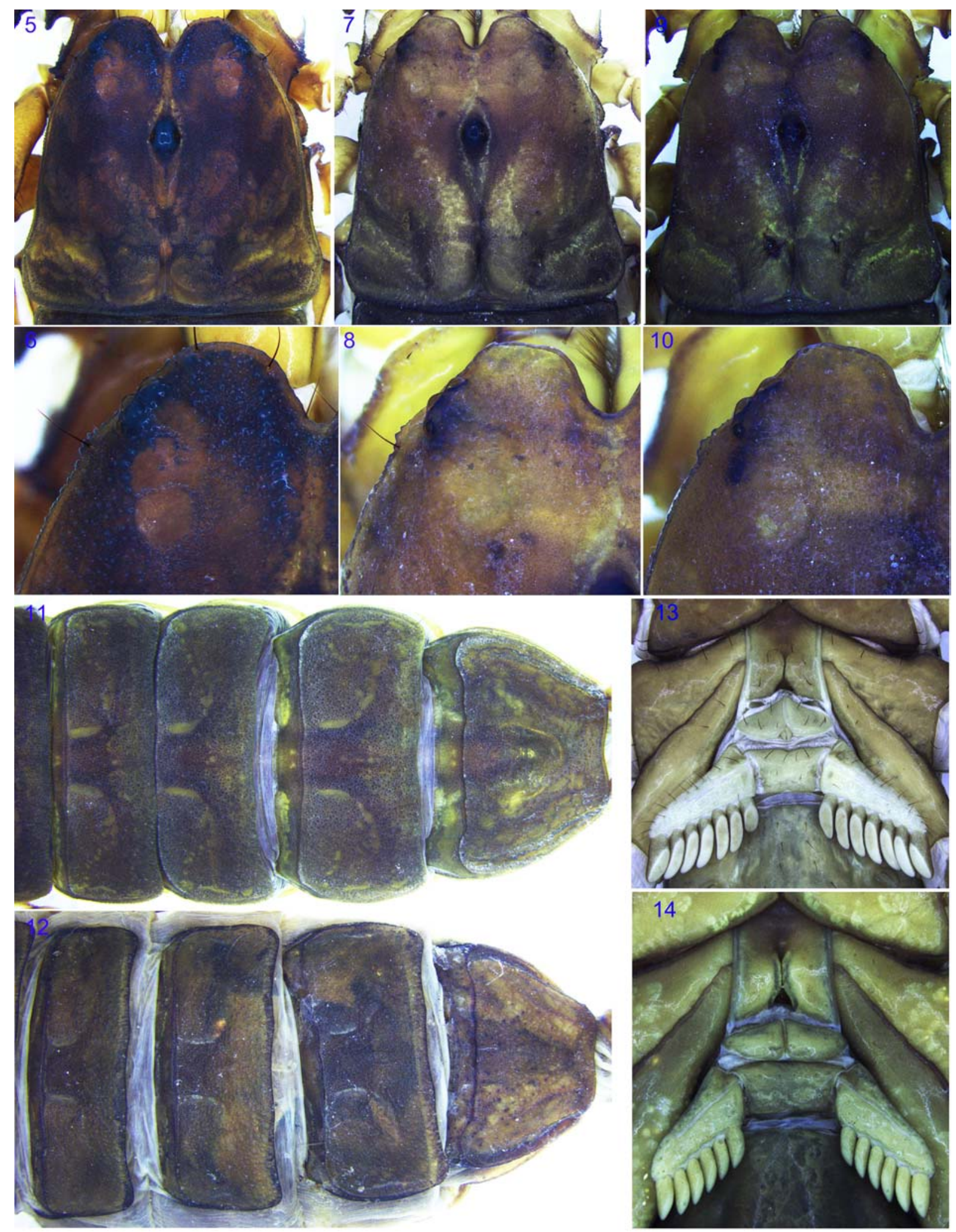

Figs 5-14. Scorpiops songi sp.n. Male holotype (5, 6, 11, 13); female paratype (Ar.-MHBU-XZLZ1502; 7, 8, 12, 14); female paratype (Ar.-MHBU-XZLZ1503; 9, 10): 5, 7, 9 - carapace; 6, 8, 10 - lateral eyes and nearby area; 11, 12 — tergites IV-VII; 13, 14 — ventral aspect of prosoma.

Рис. 5-14. Scorpiops songi sp.n. Голотип самец (5, 6, 11, 13); паратип самка (Ar.-MHBU-XZLZ1502; 7, 8, 12, 14); паратип самка (Ar.-MHBU-XZLZ1503; 9, 10): 5, 7, 9 - карапакс; 6, 8, 10 - боковые глаза и близлежащая область; 11, 12 — тергиты IV-VII; 13, 14 - просома, вентрально. 


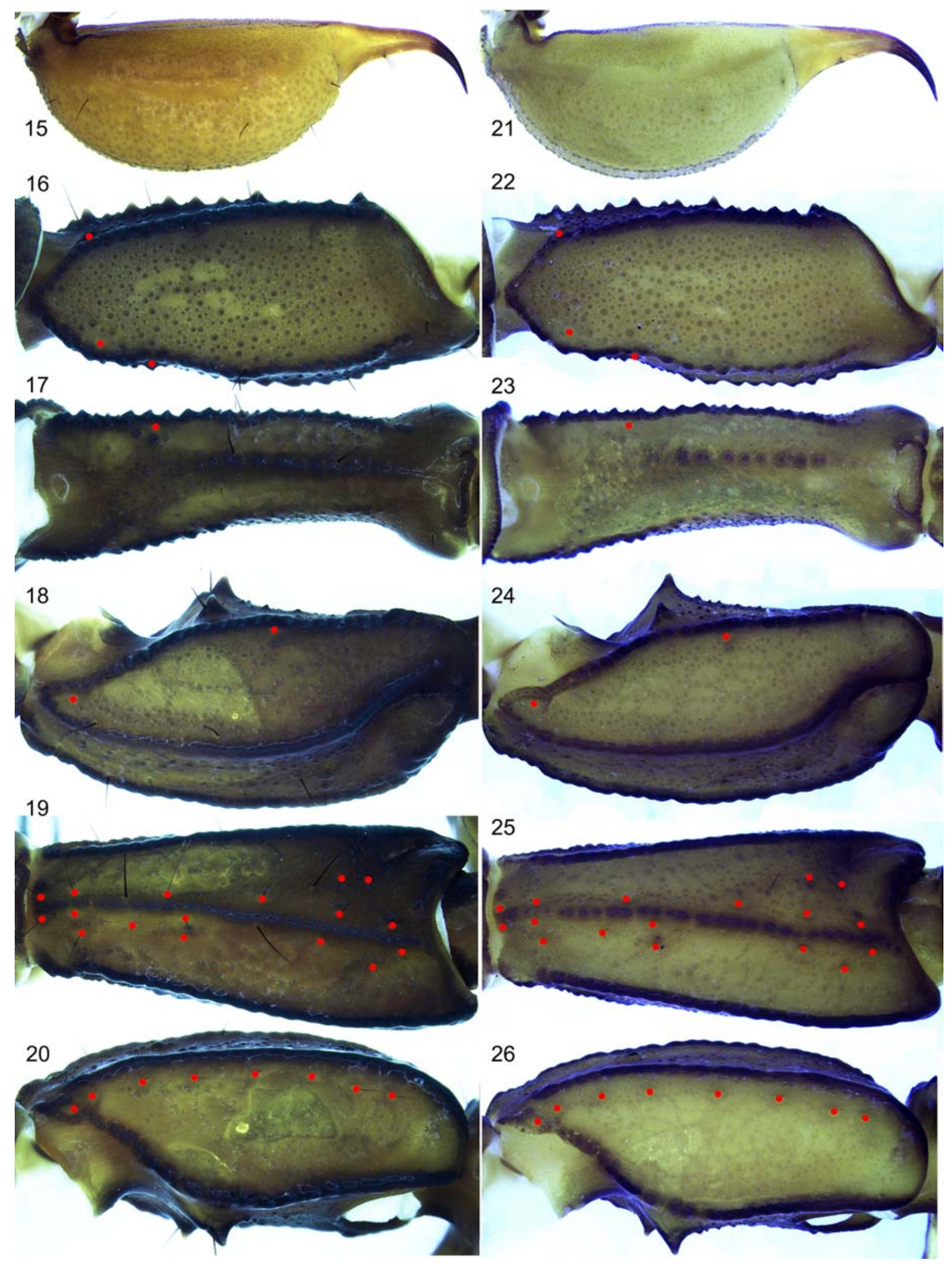

Figs 15-26. Scorpiops songi sp.n. Male holotype (15-20), female paratype (Ar.-MHBU-XZLZ1502; 21-26): 15, 21 - telson, lateral aspect; 16, 17, 22, 23 - femur (right) dorsal and external aspects; 18-20, 24-26 - patella (right) dorsal, external, and ventral aspects. Dots denote trichobothrial patterns of pedipalps.

Рис. 15-26. Scorpiops songi sp.n. Голотип самец (15-20), паратип самка (Ar.-MHBU-XZLZ1502; 21-26): 15, 21 - тельсон, латерально; 16, 17, 22, 23 - правое бедро, дорсально и снаружи; 18-20, 24-26 - правая пателла, дорсально, снаружи и вентрально. Точки указывают трихоботрии педипальп. 

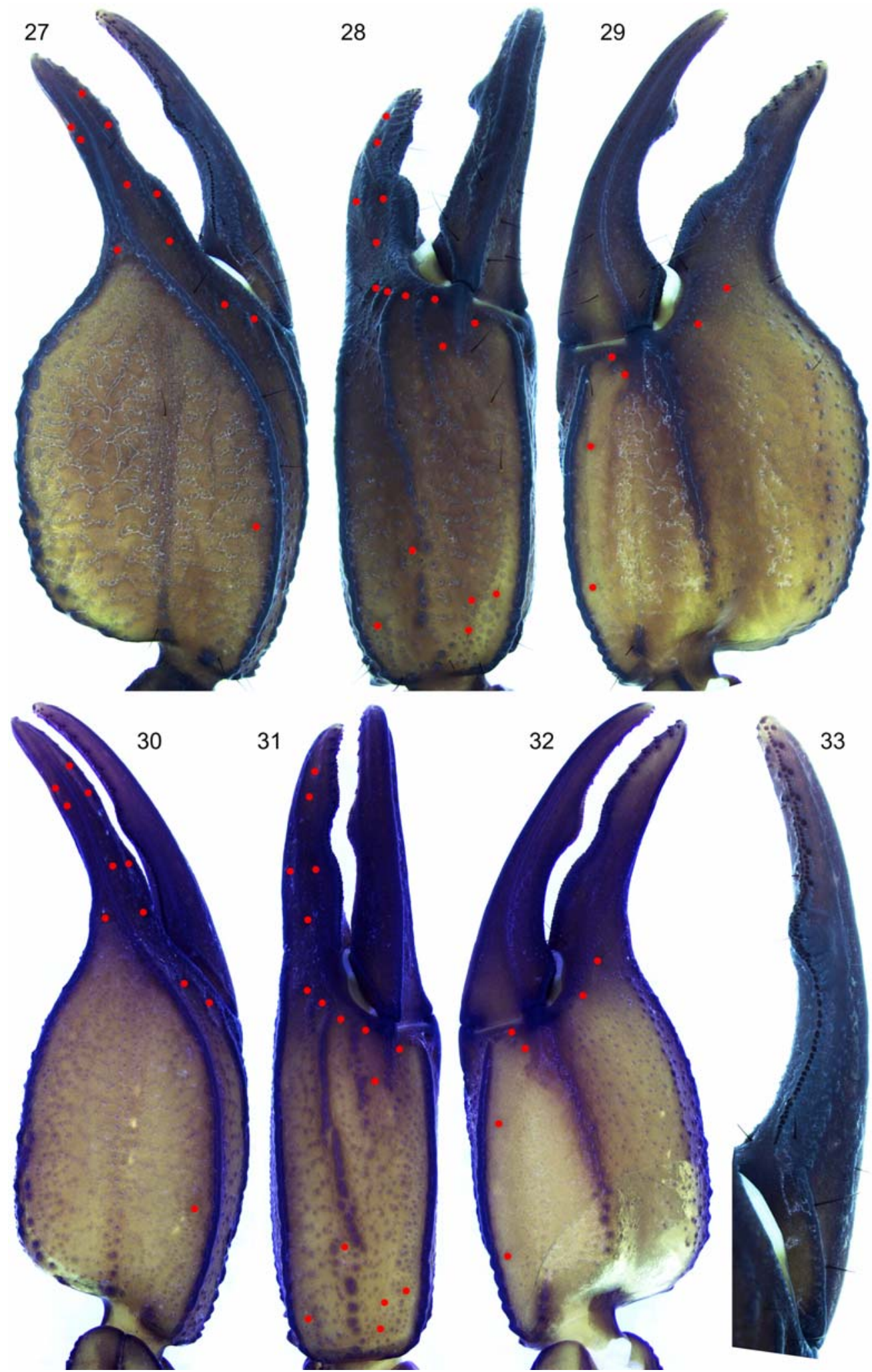

Figs 27-33. Scorpiops songi sp.n. Male holotype (27-29, 33), female paratype (Ar.-MHBU-XZLZ1502; 30-32): 27-32 - chela (right) dorsal, external, and ventral aspects; 33 - dentate margin of movable finger, showing rows of granules. Dots denote trichobothrial patterns of pedipalps.

Рис. 27-33. Scorpiops songi sp.n. Голотип самец (27-29, 33), паратип самка (Ar.-MHBU-XZLZ1502; 30-32): 27-32 — правая клешня, дорсально, снаружи и вентрально; 33 - зубчатый край подвижного пальца, показан ряд зубчиков. Точки указывают трихоботрии педипальп. 
Table 1. Measurements (in mm) of holotype (male, Ar.-MHBU-XZLZ1501) and paratype (immature female, Ar.-MHBUXZLZ1502) of Scorpiops songi sp.n. Таблица 1. Промеры (в мм) голотипа (самец, Ar.-MHBU-XZLZ1501) и паратипа (неполовозрелая самка, Ar.- MHBU-XZLZ1502) Scorpiops songi sp.n.

\begin{tabular}{|c|c|c|}
\hline \multicolumn{3}{|c|}{ Scorpiops songi sp.n. } \\
\hline & Holotype & Paratype (immature) \\
\hline Total length: & 72.0 & 61.0 \\
\hline $\begin{array}{l}\text { Carapace: } \\
\text { - Length } \\
\text { - Anterior width } \\
\text { - Posterior width }\end{array}$ & $\begin{array}{l}9.7 \\
5.2 \\
9.6\end{array}$ & $\begin{array}{l}9.4 \\
4.9 \\
8.5\end{array}$ \\
\hline $\begin{array}{l}\text { Mesosomal segments: } \\
\text { - Length }\end{array}$ & 21.7 & 20.5 \\
\hline $\begin{array}{l}\text { Metasomal segment I: } \\
\text { - Length } \\
\text { - Width } \\
\text { - Depth }\end{array}$ & $\begin{array}{l}4.2 \\
4.0 \\
3.0\end{array}$ & $\begin{array}{l}4.0 \\
3.6 \\
3.0\end{array}$ \\
\hline $\begin{array}{l}\text { Metasomal segment II: } \\
\text { - Length } \\
\text { - Width } \\
\text { - Depth }\end{array}$ & $\begin{array}{l}5.2 \\
3.7 \\
2.9\end{array}$ & $\begin{array}{l}4.4 \\
3.0 \\
2.8\end{array}$ \\
\hline $\begin{array}{l}\text { Metasomal segment III } \\
\text { - Length } \\
\text { - Width } \\
\text { - Depth }\end{array}$ & $\begin{array}{l}5.7 \\
3.3 \\
3.0\end{array}$ & $\begin{array}{l}4.8 \\
2.6 \\
2.6\end{array}$ \\
\hline $\begin{array}{l}\text { Metasomal segment IV: } \\
\text { - Length } \\
\text { - Width } \\
\text { - Depth }\end{array}$ & $\begin{array}{l}6.7 \\
3.2 \\
2.9\end{array}$ & $\begin{array}{l}5.4 \\
2.4 \\
2.6\end{array}$ \\
\hline $\begin{array}{l}\text { Metasomal segment V: } \\
\text { - Length } \\
\text { - Width } \\
\text { - Depth }\end{array}$ & $\begin{array}{l}9.8 \\
3.0 \\
2.9\end{array}$ & $\begin{array}{l}8.0 \\
2.1 \\
2.3\end{array}$ \\
\hline $\begin{array}{l}\text { Telson: } \\
\text { - Length } \\
\text { - Width } \\
\text { - Depth }\end{array}$ & $\begin{array}{c}11.3 \\
3.9 \\
3.7\end{array}$ & $\begin{array}{l}8.9 \\
3.2 \\
3.1\end{array}$ \\
\hline $\begin{array}{l}\text { Pedipalp femur: } \\
\text { - Length } \\
\text { - Width } \\
\text { - Depth }\end{array}$ & $\begin{array}{l}9.0 \\
3.8 \\
2.7\end{array}$ & $\begin{array}{l}9.3 \\
3.3 \\
3.0\end{array}$ \\
\hline $\begin{array}{l}\text { Pedipalp patella: } \\
\text { - Length } \\
\text { - Width } \\
\text { - Depth }\end{array}$ & $\begin{array}{l}7.9 \\
4.0 \\
3.5\end{array}$ & $\begin{array}{l}7.6 \\
3.9 \\
3.2\end{array}$ \\
\hline $\begin{array}{l}\text { Chela: } \\
\text { - Length } \\
\text { - Width (manus) } \\
\text { - Depth (manus) }\end{array}$ & $\begin{array}{c}17.2 \\
7.2 \\
4.7\end{array}$ & $\begin{array}{c}15.3 \\
5.6 \\
4.0\end{array}$ \\
\hline $\begin{array}{l}\text { Movable finger: } \\
\text { - Length }\end{array}$ & 10.1 & 9.5 \\
\hline Pectinal teeth & $7 / 7$ & $6 / 6$ \\
\hline
\end{tabular}

nal, ventroexternal, ventrointernal carinae granulated, and internal carinae crenulated (Figs 16, 17). Patella with dorsoexternal, dorsointernal, external, ventrointernal, ventroexternal carinae with large, smooth granules; two big spinoid granules present on the internal aspect (Figs 18-20). Trichobothrial pattern $\mathrm{C}$, neobothriotaxic; patella with 17 external trichobothria ( $5 \mathrm{eb}, 2 \mathrm{esb}, 2 \mathrm{em}, 4 \mathrm{est}, 4 \mathrm{et}$ ) and 7 or 8 ventral trichobothria (Figs 18-20). Chela with 4 ventral trichoboth- 
ria, all carinae granulated and coalesced except dorsointernal carina just with some sparse big granules (Figs 27-29). Male pedipalp chela fingers stronger curved than females (Fig. 33).

Legs: Tegument coarse with few setae, except ventral aspects of coxae, trochanters, femurs and patellae smooth. Trochanter dorsal surface with few granules. Femur dorsal surface densely granular, internally with one granular carina. Patella dorsal surface densely granular, with dorsoexternal, dorsal and ventroexternal granular carinae. Tibiae without spurs. Basitarsus with more setae, and two lateral pedal spurs. Tarsus ventrally with row of spinules. Ungues falcate.

VARIATION. Female and male paratypes: coloration more dark in metasoma, sternites and tergites (Figs 3, 4), while their morphologies are similar, except the distinct in chela and pectinal teeth (Figs 3, 4, 7-10, 12, 14, 21-26, 30 32). Number (left/right) of trichobothria on the ventral surface of the pedipalp patellae: females with $8 / 8$ ( 2 individuals) and 8/7 (1), males with $8 / 8$ (2) and 7/7 (3). Number of pectinal teeth: three females with $6 / 6$, five males with $7 / 7$. Measurements in Table 1.

HABITAT. Under stones on hillsides with ruderal vegetation in Lhozhag County, about 3650 m elevation.

DISTRIBUTION. Lhozhag County $\left[28^{\circ} 11^{\prime} \mathrm{N}, 91^{\circ} 15^{\prime} \mathrm{E}\right.$; $\left.28^{\circ} 19^{\prime} \mathrm{N}, 90^{\circ} 57^{\prime} \mathrm{E}\right]$, Xizang, China.

COMMENTS. The new species appears to be related to the other light-colored species of the genus Scorpiops from Xizang: S. luridus. The latter is also the geographically closest species, but they can be readily distinguished on the basis of the following combination of characters: (i) 7 or 8 trichobothria on the ventral surface of the pedipalp patella in $S$. songi sp.n., while there are 9 in $S$. luridus; (ii) pectinal teeth count 7 in males and 6 in females in.S. songi sp.n., pectinal teeth count $9 / 10$ in male holotype and 8 in female paratype in $S$. luridus.

Key to SPeCies of Scorpiops from China (Maps $1 \& 2$, MODIFIED FROM YIN ET AL., 2015)

1. Pedipalp chela fingers with non-scalloped (nearly straight) margins in both sexes

- Pedipalp chela fingers with scalloped margins in male adults .................................................................. 5

2. Chela length to width ratio more than 3.0 ......................... 3

- Chela length to width ratio less than 3.0 ............................ 4

3. Total length $40.0-58.0 \mathrm{~mm}$, chela length to width ratio about 3.3-3.5 ......................................... S. leptochirus

- Total length $35.2 \mathrm{~mm}$ (male holotype), chela length to width ratio about 3.2 ................................. S. taxkorgan

4. Ventral trichobothria on patella number 6 (7 rarely), pectinal teeth number $4-5$............................. S. jendeki

- Ventral trichobothria on patella number 8 , pectinal teeth number 6-8 ........................................ S. jingshanensis

5. Manus length to width ratio visibly more than 1 .......... 6

- Manus with similar length and width .............................. 13

6. Total length more than $61.0 \mathrm{~mm}$ usually ........................ 7

- Total length less than $61.0 \mathrm{~mm}$ usually ............................. 9

7. Red brown, ventral patella of pedipalps with 7 (rarely 6 or 8) trichobothria ……........................................ . petersii

- Lighter than red brown .................................................. 8

8. Ventral patella of pedipalps with 7 or 8 trichobothria, pectinal teeth count 7 in males and 6 in females
- Ventral patella of pedipalps with 9 trichobothria, pectinal teeth count $9 / 10$ in male holotye and 8 in female paratype S. luridus

9. Dorsally flat manus of pedipalps and chela of both sexes, with length/width ratio: 2.1-2.2 (about 2.1 in males and 2.2 in females), total length $40.0-50.0 \mathrm{~mm}$ in adults ....

S. margerisonae

- Dorsally round manus of pedipalps or at least the chela of one sex, with length to width ratio more than 2.2 or total length more than $50.0 \mathrm{~mm}$

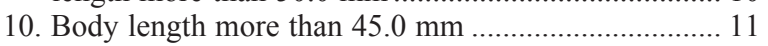

-Body length less than $40.0 \mathrm{~mm}$........................................ 12

11. Patella of pedipalp with 17 (5 eb, $2 \mathrm{esb}, 2 \mathrm{em}, 4 \mathrm{est}, 4 \mathrm{et})$ external trichobothria ................................... S. tibetanus

- Patella of pedipalp with 18-20 (5 eb, $2 \mathrm{esb}, 2 \mathrm{em}, 5 \mathrm{est}, 4$ 6 et) external trichobothria .................... S. wrzecionkoi

12. Chela of pedipalp length to width ratio about 2.6-3.0 .. S. lhasa

- Chela of pedipalp length to width ratio less than 2.5 ........ S. atomatus

13. Yellow brown color, length of adults more than $70.0 \mathrm{~mm}$ S. ingens

- Red brown to red black color, length of adults less than $65.0 \mathrm{~mm}$............................... S. hardwickii "complex"

\section{Discussion}

Di et al. [2011a] according to the revision of the genus Scorpiops published by Kovařík [2000], and further considerations given by Kovař́k \& Ahmed [2009], summarized the features of S. hardwickii (Gervais, 1843) "complex" (three species from China: $S$. hardwickii, S. langxian and S. pococki): 6-8 ventral trichobothria and 17 external trichobothria on the patella; pectinal teeth number count 4-9; pectines without fulcra; chela manus length to width ratio about 1 ; tegument coarse. S. hardwickii "complex" can be distinguished from $S$. jendeki by the following features: (1) carapace with dense granules in S. hardwickii "complex", while in $S$. jendeki bearing very sparse large granules; (2) the manus of pedipalps dorsally with coalescing large granules forming clear dorsoexternal carinae in S. hardwickii "complex"; in S. jendeki, irregular rows of granules form a loose dorsoexternal carinae; (3) chela fingers scalloped in S. hardwickii "complex", while they are non-scalloped (nearly straight) in S. jendeki. S. hardwickii "complex" can't be distinguished from $S$. jingshanensis except the body length of the latter is very short (the authors did not provide its body length as they thought it were immature) and its pedipalp chela fingers with non-scalloped (nearly straight) margins in both sexes.

Acknowledgments. We thank Prof. Roger D. Farley (University of California, Riverside), in particular, for linguistic improvement. This work was supported by grants to Zhiyong Di from the National Natural Sciences Foundation of China (31970403 and 31601871), the Hebei Provincial Natural Science Foundation (C2019201273), and the Advanced Talents Incubation Program of the Hebei University (801260201276). 


\section{References}

Bastawade D.B. 2006. Arachnida: Scorpionida, Uropygi, Schizomida and Oncopodid Opiliones (Chelicerata) // Fauna of Arunachal Pradesh. State Fauna Series. Vol.13. Part 2. Zool. Survey, India. P.449-465.

Di Z.Y., He Y.W., Cao Z.J., Wu Y.L., Li W.X. 2011a. The first record of the family Euscorpiidae (Arachnida: Scorpiones) from Central China, with a key of Chinese species of the genus Scorpiops // Euscorpius. No.118. P.1-9.

Di Z.Y., He Y.W., Wu Y.L., Cao Z.J., Liu H., Jiang D.H., Li W.X 2011b. The scorpions of Yunnan (China): updated identification key, new record and redescriptions of Euscorpiops kubani and E. shidian (Arachnida, Scorpiones) // ZooKeys. Vol.82. P.1-33.

Di Z.Y., Xu X.B., Cao Z.J., Wu Y.L., Li W.X. 2013. Notes on the scorpions (Arachnida, Scorpiones) from Tibet with the redescription of Scorpiops jendeki Kovař́k, 2000 (Scorpiones, Euscorpiidae) from Yunnan (China) // ZooKeys. Vol.301. P.5199.

Di Z.Y., Yang Z.Z., Cao Z.J., Wu Y.L., Li W.X. 2015. The Scorpiones Fauna of China (Chelicerata: Arachnida) // Acta Arachnologica Sinica. Vol.24. P.109-115.

Di Z.Y., Yang Z.Z., Yin S.J., Cao Z.J., Li W.X. 2014. History of study, updated checklist, distribution and key of scorpions (Arachnida: Scorpiones) from China // Zoological Research. Vol.35. P.3-19.

Hjelle J.T. 1990. Anatomy and morphology // Polis G.A. (ed.). The Biology of Scorpions. Stanford: Stanford Univ. Press. P.9-63.

Kovařík F. 2000. Revision of family Scorpiopidae (Scorpiones) with descriptions of six new species // Acta Societatis Zoologicae Bohemicae.Vol.64. P.153-201.

Kovař́k F. 2020. Nine new species of Scorpiops Peters, 1861 (Scorpiones: Scorpiopidae) from China, India, Nepal, and $\mathrm{Pa}-$ kistan // Euscorpius. No.302. P.1-43.

Kovař́k F., Ahmed Z. 2009. Three new species of the genus Scorpiops Peters, 1861 (Scorpiones: Euscorpiidae: Scorpiopinae) from Pakistan // Euscorpius. No.88. P.1-11.
Li W.X., Wu Y.L., Cao Z.J., Di Z.Y. 2016. The taxonomy of the order Scorpiones in China // Li W.X., Wu Y.L., Cao Z.J., Di Z.Y. (eds.). Scorpion biology and toxins. Beijing: Science Press. P.230-231.

Lourenço W.R. 2018. Scorpions at high altitudes: A new species of Scorpiops Peters, 1861 (Scorpiones: Scorpiopidae) from the Taxkorgan Reserve, Xinjiang, China // Comptes Rendus Biologies.Vol.341. P.362-369.

Qi J.X., Zhu M.S., Lourenço W.R. 2005. Eight new species of the genera Scorpiops Peters, Euscorpiops Vachon, and Chaerilus Simon (Scorpiones: Euscorpiidae, Chaerilidae) from Tibet and Yunnan, China // Euscorpius. No.32. P.1-40.

Sissom W.D., Polis G.A., Wait D.D. 1990. Field and laboratory methods // Polis G.A. (ed.). The Biology of Scorpions. Stanford: Stanford Univ. Press. P.445-461.

Soleglad M., Sissom W.D. 2001. Phylogeny of the family Euscorpiidae Laurie, 1869 (Scorpiones): a major revision // Fet V., P.A. Selden (eds.). Scorpions 2001. In Memoriam Gary A. Polis. Burnham Beeches, Bucks: British Arachnological Society. P.25-111.

Vachon M. 1952. Études sur les Scorpions. Publications de l'Institut Pasteur d' Algérie. Algérie, Alger. 482 p.

Vachon M. 1974. Étude des caractères utilisés pour classer les familles et les genres de Scorpions (Arachnides). 1. La trichobothriotaxie en arachnologie. Sigles trichobothriaux et types de trichobothriotaxie chez les Scorpions // Bulletin du Muséum national d'Histoire naturelle, Paris, 3 sér. Vol.140. P.857-958.

Yin S.J., Zhang Y.F., Pan Z.H., Li S.B., Di Z.Y. 2015. Scorpiops ingens sp.n. and an updated key to the Scorpiops from China (Scorpiones, Euscorpiidae, Scorpiopinae) // Zookeys. Vol.495. P.53-61.

Zhu M.S., Qi J.X., Song D.X. 2004. A checklist of scorpions from China (Arachnida: Scorpiones) // Acta Arachnologica Sinica. Vol.13. P.111-118.

Responsible editor K.G. Mikhailov 